\title{
Protective effects of hesperetin on lipopolysaccharide-induced acute lung injury in a rat model
}

\author{
Bir sıçan modelinde lipopolisakkarit uyarımlı akut akciğer hasarı üzerine \\ hesperetinin koruyucu etkileri
}

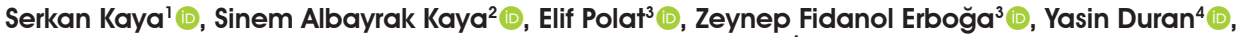

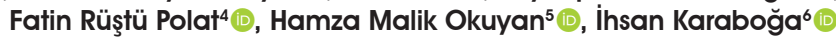 \\ Institution where the research was done: \\ Tekirdağ Namık Kemal University, Tekirdağ, Turkey \\ Author Affiliations: \\ 'Department of Thoracic Surgery, Tekirdağ Namık Kemal University, Faculty of Medicine, Tekirdağ, Turkey \\ ${ }^{2}$ Department of Midwifery, Biruni University, Faculty of Health Sciences, Istanbul, Turkey \\ ${ }^{3}$ Department of Histology and Embriology, Tekirdağ Namık Kemal University, Faculty of Medicine, Tekirdağ, Turkey \\ ${ }^{4}$ Department of General Surgery, Tekirdağ Namık Kemal University, Faculty of Medicine, Tekirdağ, Turkey \\ ${ }^{5}$ Department of Medical Services and Techniquies, Mustafa Kemal University, Hatay Vocational School of Health Sciences, Hatay, Turkey \\ ${ }^{6}$ Department of Emergency and Disaster Medicine, Tekirdağ Namık Kemal University, School of Health, Tekirdağ, Turkey
}

\begin{abstract}
Background: In this experimental study, we aimed to investigate the effects of hesperetin, a natural flavonoid, on a lipopolysaccharideinduced acute lung injury model in rats.

Methods: Between March 2019 and May 2019, a total of 18 adult male Wistar albino rats, weighing approximately 250 to $300 \mathrm{~g}$, were randomly divided into three groups as control, lipopolysaccharide, and lipopolysaccharide + hesperetin groups ( $\mathrm{n}=6$ in each group). The wet/dry weight ratio of lung tissue was determined. Histopathological changes were examined using light and scanning electron microscopy. Pulmonary nuclear factor-kappa beta, inducible nitric oxide synthase, and alpha-smooth muscle antigen activity were determined with indirect immunohistochemical methods. Pulmonary apoptosis was detected with the terminal deoxynucleotidyl transferase dUTP nick-end labeling method. Tumor necrosis factor-alpha, interleukin-1 beta, interleukin-6, and interleukin-10 concentrations were measured with enzyme-linked immunosorbent assay.
\end{abstract}

Results: Treatment with hesperetin significantly improved the architecture of lung tissue and reduced the wet/dry weight ratio, nuclear factor-kappa beta, inducible nitric oxide synthase, and alphasmooth muscle antigen expression, pulmonary apoptosis, and levels of proinflammatory cytokines.

Conclusion: Our study results suggest that hesperetin has a potent protective effect against lipopolysaccharide-induced acute lung injury in rats via suppression of the proinflammatory cytokine cascade, nuclear factor-kappa beta, signaling pathway activation, and apoptosis.

Keywords: Acute lung injury, inducible nitric oxide synthase, lipopolysaccharide, nuclear factor-kappa beta, pulmonary apoptosis, tumor necrosis factor-alpha.
$\ddot{O} Z$

Amaç: Bu deneysel çalışmada, doğal bir flavonoid olan hesperetinin sıçanlarda lipopolisakkarit uyarımlı akut akciğer hasar modeli üzerindeki etkileri incelendi.

Çalışma planı: Mart 2019 - Mayıs 2019 tarihleri arasında ağırlıkları yaklaşık 250-300 g olan toplam 18 erişkin erkek Wistar albino sıçan, kontrol, lipopolisakkarit ve lipopolisakkarit + hesperetin grubu olmak üzere rastgele üç gruba ayrıldı (her grupta $\mathrm{n}=6$ ). Akciğer dokusunda 1slak/kuru ağırlık oranı belirlendi. Histopatolojik değişiklikler 1 şı ve elektron mikroskobu ile incelendi. Pulmoner nükleer faktör-kappa beta, indüklenebilir nitrik oksit sentaz ve alfa-düz kas antijeni indirekt immünohistokimyasal yöntem ile belirlendi. Pulmoner apoptoz, terminal deoksinükleotidil transferaz dUTP çentik uç işaretleme yöntemi ile belirlendi. Tümör nekroz faktör-alfa, interlökin-1 beta, interlökin- 6 ve interlökin-10 konsantrasyonları enzim bağlı immunosorbent testi ile belirlendi.

Bulgular: Hesperetin tedavisi akciğer doku mimarisini anlamlı düzeyde iyileştirdi ve 1slak/kuru ağırlık oranı, nükleer faktör-kappa beta, indüklenebilir nitrik oksit sentaz ve alfa-düz kas antijeni ekspresyonu, pulmoner apoptoz ve proinflamatuvar sitokin düzeylerini azaltt1.

Sonuç: Çalışma sonuçlarımız, hesperetinin sıçanlarda proinflamatuvar sitokin kaskadı, nükleer faktör-kappa beta sinyal yolağı aktivasyonu ve apoptozun baskılanması ile lipopolisakkarit uyarımlı akut akciğer hasarına karşı güçlü bir koruyucu etkiye sahip olduğunu göstermektedir. Anahtar sözcükler: Akut akciğer hasarı, indüklenebilir nitrik oksit sentaz, lipopolisakkarit, nükleer faktör-kappa beta, pulmoner apoptoz, tümör nekroz faktör-alfa.

Received: September 29, 2019 Accepted: January 22, 2020 Published online: April 22, 2020

Correspondence: İhsan Karaboğa. Tekirdağ Namık Kemal Üniversitesi, Sağlık Yüksekokulu, Acil Yardım ve Afet Yönetimi Bölümü, 59030 Tekirdağ, Türkiye. Tel: +90 530 - 9028009 e-mail: insankaraboga@gmail.com 
Acute lung injury (ALI), a serious complication with high morbidity and mortality rates caused by sepsis, chest trauma, ischemia-reperfusion, viral pneumonia, and burns and is characterized by histopathological changes such as diffuse pulmonary alveolar infiltration, pulmonary edema, apoptosis, and hyaline membrane formation..$^{[1-3]}$ Thoracic surgery is also an important risk factor for the development of ALI and the incidence of ALI after pneumectomy has been reported to be $7.9 \%$. A period of 10 days after thoracotomy is considered a critical period for the development of ALI. ${ }^{[4]}$

Lipopolysaccharide (LPS) located in the Gram-negative bacterial wall structure is released extracellularly and is considered the predominant microbial inducer of inflammation, as it initiates the innate immune response at the onset of ALI. ${ }^{[5,6]}$ Therefore, in preclinical experimental studies, LPS is widely used as an effective strategy in the formation of the clinically relevant form of ALI in experimental animal models. ${ }^{[1,7]}$

The inflammatory cell infiltration and inflammation, which play a major role in the pathogenesis of ALI and are highly responsible for the occurrence of tissue damage, are also associated with overexpression of proinflammatory cytokines. ${ }^{\left[{ }^{8]}\right.}$ With LPS stimulation, the release of proinflammatory cytokines such as tumor necrosis factor-alpha (TNF$\alpha$ ), interleukin (IL)-1 beta (IL-1 $\beta$ ) and IL-6, mainly produced by inflammatory cells and elevated levels in the lung, and activation of the cytokine cascade accelerate tissue damage in the lung. ${ }^{[2,3]}$ In previous studies, nuclear factor-kappa beta $(\mathrm{Nf}-\kappa \beta)$, the regulator of proinflammatory cytokines required for ALI development, played an important role in the pathogenesis of inflammation-related pulmonary diseases. ${ }^{[9-11]}$ Therefore, agents which inhibit Nf- $\kappa \beta$ activation are thought to be useful in reducing pulmonary inflammation and tissue damage. ${ }^{[12]}$

Hesperetin is a natural bioflavonoid found abundantly in some citrus fruits. ${ }^{[13]}$ Antioxidative, ${ }^{[13]}$ antiproliferative, ${ }^{[14]}$ antiviral, ${ }^{[15]}$ antiapoptotic, ${ }^{[16]}$ and anti-inflammatory. ${ }^{[17,18]}$ bioactivities of hesperetin have been demonstrated in many previous experimental studies. Moreover, previous studies have shown that hesperetin reduces proinflammatory cytokine expression by suppressing Nf- $\kappa \beta$ activation and inhibits tissue damage in the lung. ${ }^{[13,19]}$

In the present study, we aimed to investigate whether hesperetin could inhibit the production of proinflammatory cytokines and reduce the severity of pulmonary edema, injury, and apoptosis in an LPSinduced ALI model in rats.

\section{MATERIALS AND METHODS}

\section{Chemicals}

Hesperetin was provided by Santa Cruz (Santa Cruz Biotech., Dallas, TX, USA). The LPS (Escherichia coli [E. coli], O26:B6 serotype) and Masson's trichrome kit were purchased from Sigma Pharmaceuticals (SigmaAldrich, St. Louis, MO, USA). Hematoxylin-Eosin (H-E) and terminal deoxynucleotidyl transferase dUTP nick end labeling (TUNEL; S7100 ApopTag ${ }^{\circledR}$ Plus Peroxidase In Situ) kits were purchased from Merck Pharmaceuticals (Merck KGaA, Darmstadt, Germany). Ketamine was provided by Pfizer Pharmaceuticals (Pfizer Inc., Istanbul, Turkey) and xylazine was provided by Bayer Pharmaceuticals (Bayer Inc., Mississauga, Canada). The Nf- $\kappa \beta$, inducible nitric oxide synthase (iNOS), and alpha-smooth muscle antigen ( $\alpha$-SMA) primary antibodies were provided by Novus Biologicals (Novus Biologicals Inc., Littleton, CO, USA). The TNF- $\alpha$, IL-6, IL-10, and IL-1 $\beta$ enzyme-linked immunosorbent assay (ELISA) kits were provided by Shangai Biotech (Shangai YL Biotech Co., Shanghai, China).

\section{Animals}

Between March 2019 and May 2019, a total of 18 adult male Wistar albino rats, weighing approximately 250 to $300 \mathrm{~g}$, were obtained from Tekirdağ Namık Kemal University, Application and Research Center for Experimental Animals (DHUAM). The rats were housed at DHUAM in standard laboratory conditions (temperature $22 \pm 2^{\circ} \mathrm{C}$; humidity 40 to $60 \%$; $12 / 12$ dark/light cycle) and were fed with pellet food and tap water ad libitum during experimental procedures. The study protocol was approved by the institutional Animal Ethics Committee of Tekirdağ Namık Kemal University. All experimental procedures were carried out in accordance with the Guide for the Care and Use of Laboratory Animals proposed by the National Institute of Health.

\section{Experimental design}

All rats were randomly divided into three groups as the control, LPS, and LPS+hesperetin $(n=6$ in each). To induce ALI, LPS (10 $\mathrm{mg} / \mathrm{kg}$, dissolved in $0.5 \mathrm{~mL}$ sterile saline solution) was given in single intraperitoneal administration from E. coli. Hesperetin treatment $(100 \mathrm{mg} / \mathrm{kg}$, dissolved in $0.5 \mathrm{~mL}$ sterile saline solution) was administered $15 \mathrm{~min}$ after LPS induction orally. ${ }^{[17]}$ Twenty-four $\mathrm{h}$ after the LPS injection, all rats were anesthetized (ketamine/ 
xylazine; 90/10 mg/kg), and intracardiac blood and lung tissues were obtained for further analysis.

\section{Lung wet/dry weight ratio}

The fresh left superior lobe from each rat was washed in phosphate buffer saline, blotted and weighed for the evaluation of pulmonary edema. The wet/dry (W/D) weight ratio was calculated by reweighing samples held for $24 \mathrm{~h}$ at $80^{\circ} \mathrm{C}$ according to a previous study. ${ }^{[19]}$

\section{Histopathological analysis}

A portion of the right lung lobe was used for histopathological and immunohistochemical examination, while the other part was used for scanning electron microscopic (SEM) examination. The lung tissue specimens were fixed in $10 \%$ neutral buffered formalin for $48 \mathrm{~h}$. After fixation, the samples were washed with tap water, dehydrated in graded ethanol, cleared in xylene, and embedded in paraffin. The paraffin blocks were sectioned with rotary microtome (Slee, MPS, Germany) at $5 \mu \mathrm{m}$-thick and stained with $\mathrm{H}-\mathrm{E}$ according to a previous study. ${ }^{[20]}$ Histopathological changes were analyzed and graded by two pathologists blinded to the groups. Histopathological changes were scored on H-E-stained lung slides for the degree of intraalveolar edema, intraalveolar hemorrhage, and neutrophil infiltration using grades 0 to $4(0$; none, 1 ; mild, 2; moderate, 3; severe, 4; overwhelming) with a maximum score of 12 , according to previous study. ${ }^{[21]}$ Also, the lung sections were stained with Masson's trichrome staining. All histopathological examinations were performed using the Olympus CX41 (Olympus, Japan) light microscope and image analysis system (Kameram Gen III Image Analysis Software, Istanbul, Turkey).

\section{SEM analysis}

For ultrastructural analysis of the lung tissue, the lung specimens were fixed in 2\% 4-(2-hydroxyethyl)1-piperazineethanesulfonic acid (HEPES)-buffered glutaraldehyde solution overnight at $4^{\circ} \mathrm{C}$. After the fixation process, the tissues were washed with $0.1 \mathrm{M}$ HEPES and dehydrated with ethanol. They were dried using hexamethyldisilane. The specimens were examined using scanning electron microscopy (Quanta FEG 250, FEI Technologies Inc., OR, USA) at DHUAM of Tekirdağ Namık Kemal University, Faculty of Medicine.

\section{Immunohistochemical examination}

For immunohistochemical detection of nuclear factor-kappa beta (Nf- $\kappa \beta)$, iNOS, and $\alpha$-SMA expression in lung tissue, paraffin-embedded lung tissue specimens had the avidin biotin - peroxidase complex technique. ${ }^{[22]}$ Anti-Nf- $\kappa \beta$ (1:100), anti-iNOS (1:100), and anti- $\alpha$-SMA (1:100) primary antibodies were incubated in a humidified chamber. Biotin-streptavidin detection kit was used as secondary antibodies. In addition, 3-amino-9-ethylcarbazole (AEC) was used as a chromogen to create contrast. Counterstain was performed with Mayer's hematoxylin. The iNOS and $\mathrm{Nf}-\kappa \beta$-positive-stained cell numbers were calculated as positive cells $/ \mathrm{mm}^{2}$, and $\alpha$-SMA immunoreactivity was calculated as percentage for each group.

\section{Pulmonary apoptosis}

Apoptotic cells in the lung parenchyma were determined by the TUNEL staining method, which marks the ends of broken deoxyribonucleic acid fragments. The TUNEL kit was used. As a chromagen, 3,3'-diaminobenzidine (DAB) was used to create contrast. Contrasting stains were made with Mayer's hematoxylin, and cells with dense dark-brown stained nuclei were considered apoptotic cells. Apoptotic cells were calculated as positive cells $/ \mathrm{mm}^{2}$ for each group.

\section{Cytokine assays}

The levels of proinflammatory cytokines TNF- $\alpha$, IL-1 $\beta$ and IL-6, and anti-inflammatory IL-10 were determined using commercially available ELISA ELISA kits according to the manufacturer's instructions in $\mathrm{pg} / \mathrm{mL}$. The TNF- $\alpha$ and IL- $1 \beta$ were determined in pulmonary tissue, while IL-6 and IL-10 were examined in serum. Cytokine levels were calculated according to standard curves (Multiskan ${ }^{\mathrm{TM}}$ GO microplate spectrophotometer, Thermo Fisher Scientific Inc., MA, USA).

\section{Statistical analysis}

Statistical analysis was performed using the IBM SPSS version 21.0 software (IBM Corp., Armonk, NY, USA). Descriptive data were expressed in mean \pm standard error of mean (SEM). The numerical parameters of the groups were evaluated using a nonparametric Kruskal-Wallis test, while the significance of the values obtained in two-way comparisons was measured using the Mann-Whitney U test. A $p$ value of $<0.05$ was considered statistically significant.

\section{RESULTS}

Figure 1 shows the light and electron microscopic examination findings for the lung tissue. The control group had no histopathological alterations (Figure 1a, d, and g). The LPS group showed an increased inflammatory cell infiltration, alveolar wall thickness, hemorrhage, and edema in lung 

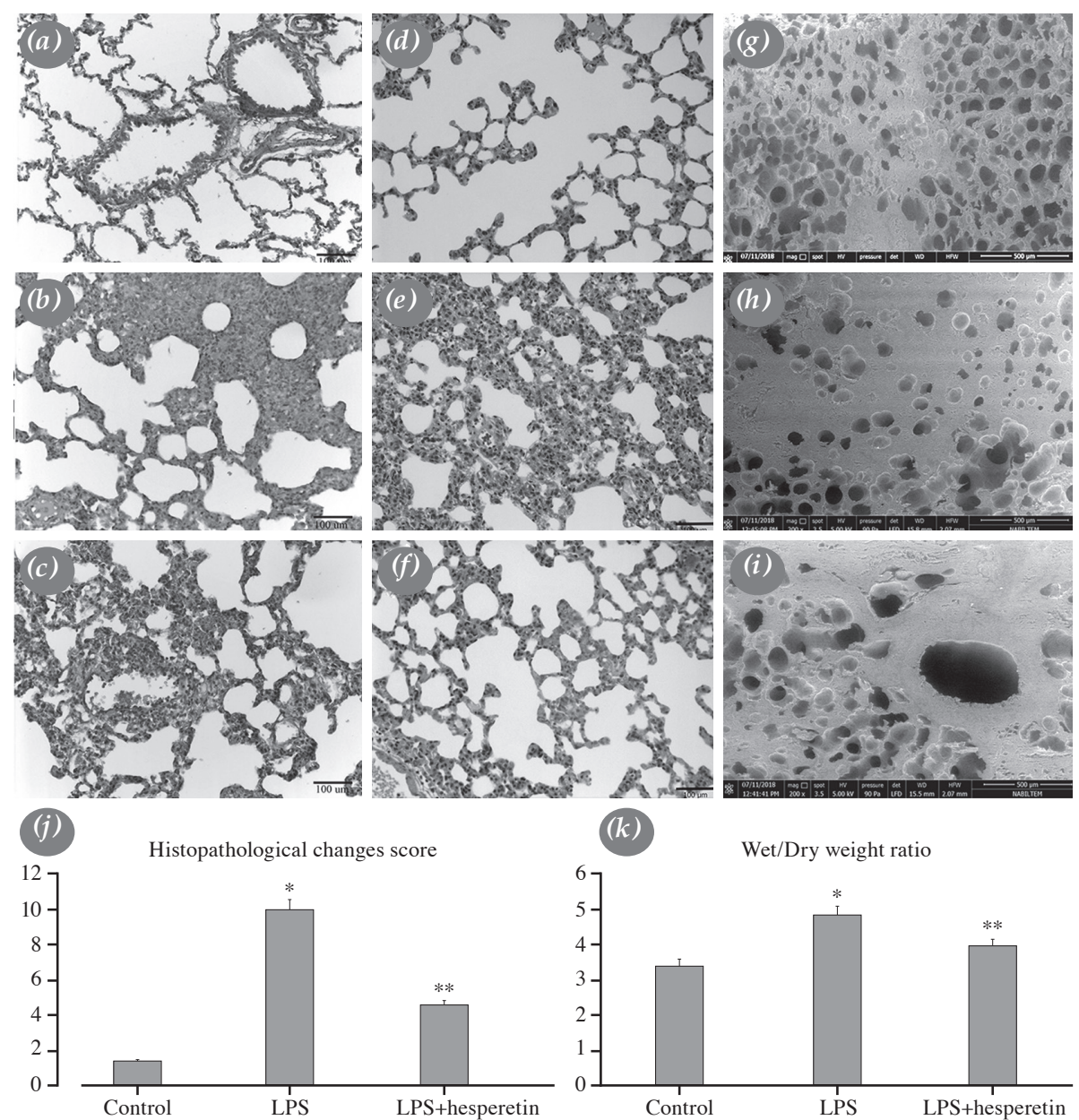

Figure 1. Histopathological examination of hesperetin on LPS-induced ALI. (a-c) H-E stained lung sections, (a) control, (b) LPS and (c) LPS+hesperetin. (d-f) Masson's trichrome stained lung sections, (d) control, (e) LPS and (f) LPS+hesperetin. (g-i) Ultrastructural SEM examination of lung tissue; (g) control, (h) LPS and (i) LPS+hesperetin. (j) comparison of histopathological changes scores of groups, (k) comparison of the W/D weight ratio findings. ALI: Acute lung injury; LPS: Lipopolysaccharide; SEM: Scanning electron microscopic; * $\mathrm{p}<0.05$ compared to control group; $* * \mathrm{p}<0.05$ compared to LPS group.

parenchyma (Figure 1b, e, and h). Treatment with hesperetin significantly alleviated pulmonary degeneration and histopathological change scores in the lung tissue (Figure 1c, f, g, and j). The H-E, Masson's trichrome, and SEM findings are compatible with each other.

As shown in Figure 1k, the LPS group had a significantly higher W/D ratio compared to the control group, indicating the presence of edema and inflammatory cell infiltration in the pulmonary tissue ( $\mathrm{p}=0.001)$. The LPS+hesperetin group exhibited significantly decreased W/D ratio compared to the LPS group ( $\mathrm{p}=0.002)$.
The immunohistochemical expression of $\mathrm{Nf}-\kappa \beta$, iNOS, and $\alpha$-SMA are shown in Figures 2-4. The Nf- $\kappa \beta$ immunohistochemical expression was observed as nuclear brown staining. A statistically significant decrease in the number of positively stained cells was observed in the group treated with hesperetin, despite the increase in the $\mathrm{Nf}-\kappa \beta$ immunohistochemical expression in the LPS group ( $\mathrm{p}=0.002$, Figure $2 \mathrm{~d}$ ).

The control group showed rare iNOS immunoreactivity in some alveolar epithelial cells (Figure 3a). The expression of iNOS increased, particularly in the alveolar epithelial cells and areas of inflammation, in the LPS group (Figure 3b). Decreased 

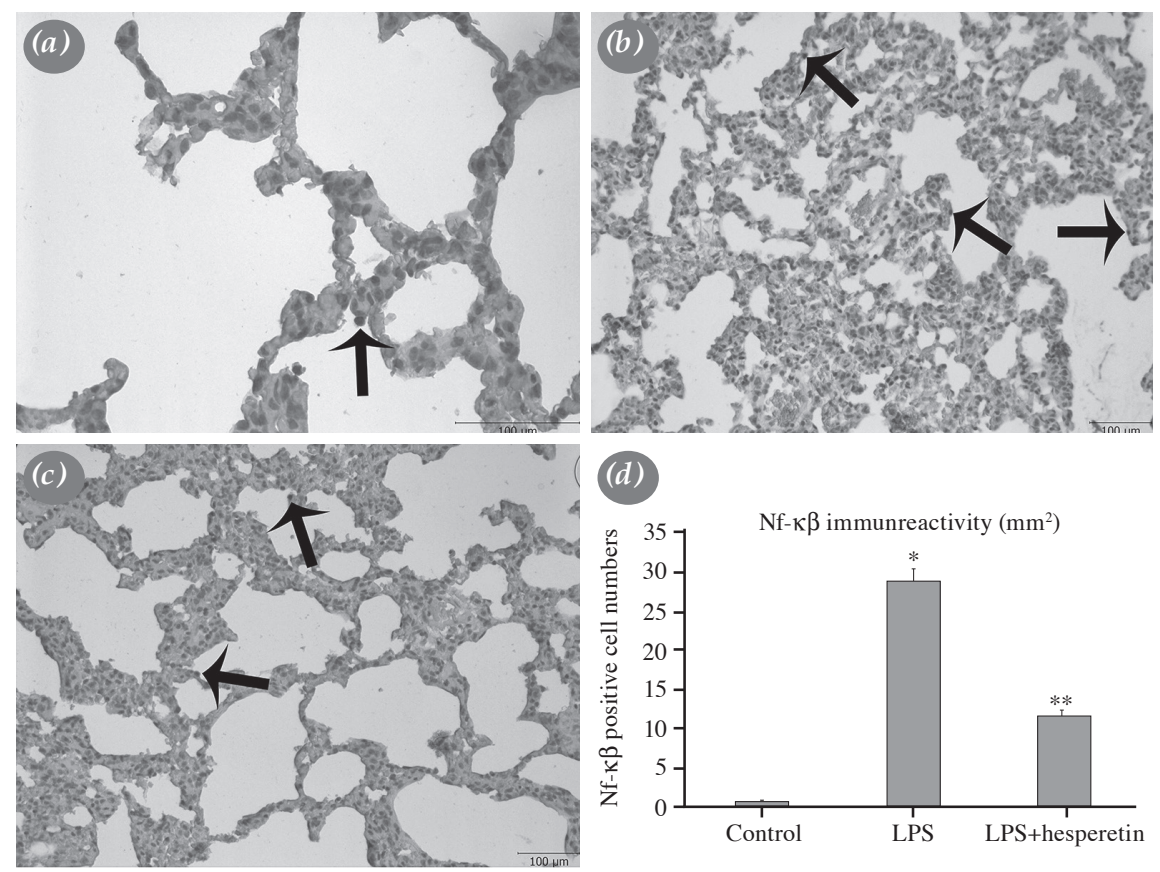

Figure 2. Immunohistochemical examination of $\mathrm{Nf}-\kappa \beta$ expression in lung tissue. (a) Control, (b) LPS and (c) LPS+hesperetin, (d) comparison of the $\mathrm{Nf}-\kappa \beta$ expression in group.

LPS: Lipopolysaccharide; Arrows; Nf-k $\beta$ - positive cells, scale bar; $100 \mu \mathrm{m}$, Mayer's hematoxylin counterstain; Nf- $\kappa \beta$ : Nuclear factor-kappa beta; $* \mathrm{p}<0.05$ compared to control group; ${ }^{* *} \mathrm{p}<0.05$ compared to LPS group.

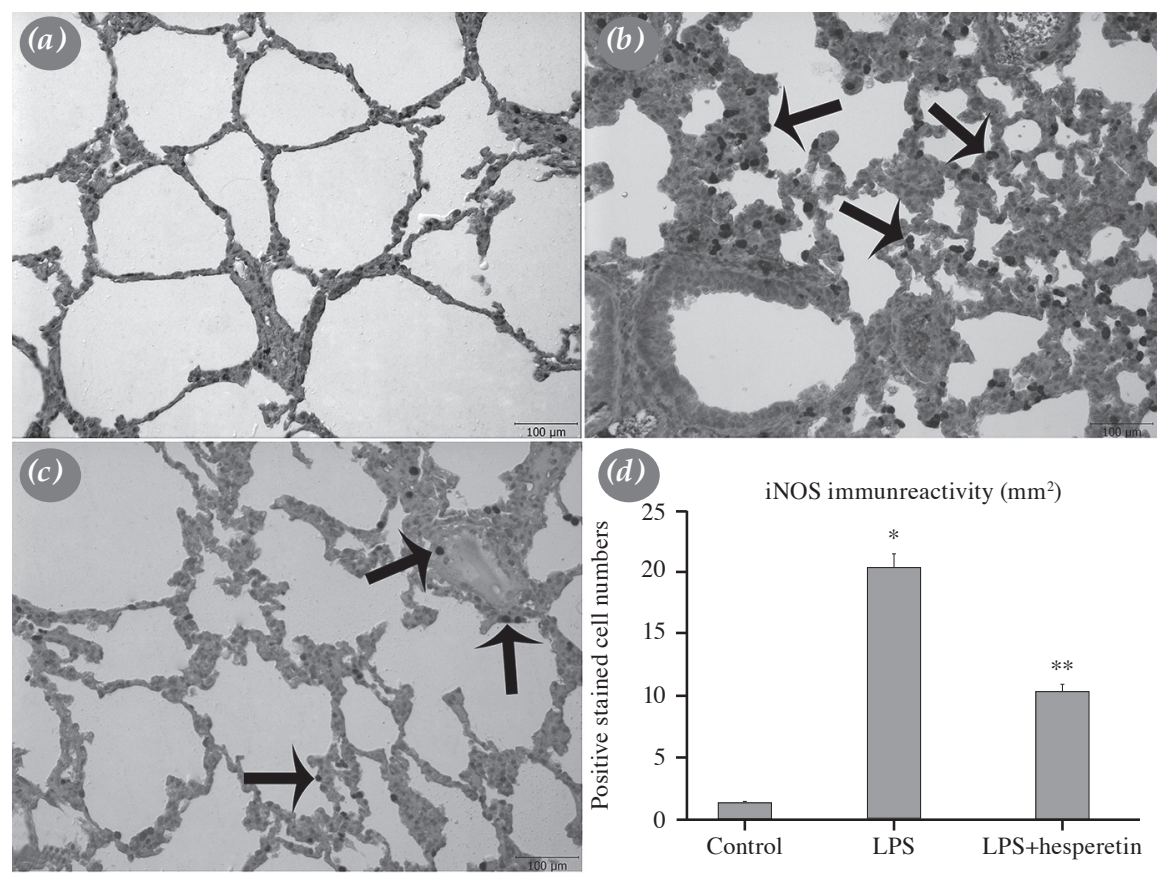

Figure 3. Effect of hesperetin on pulmonary iNOS expression. (a) Control, (b) LPS and (c) LPS+hesperetin, (d) comparison of the iNOS immunoreactivity of groups.

Arrows: iNOS-positive cells; Scale bar: $100 \mu \mathrm{m}$, Mayer's hematoxylin counterstain; iNOS: Inducible nitric oxide synthase; LPS: Lipopolysaccharide; * $\mathrm{p}<0.05$ compared to control group; ** $\mathrm{p}<0.05$ compared to LPS group. 

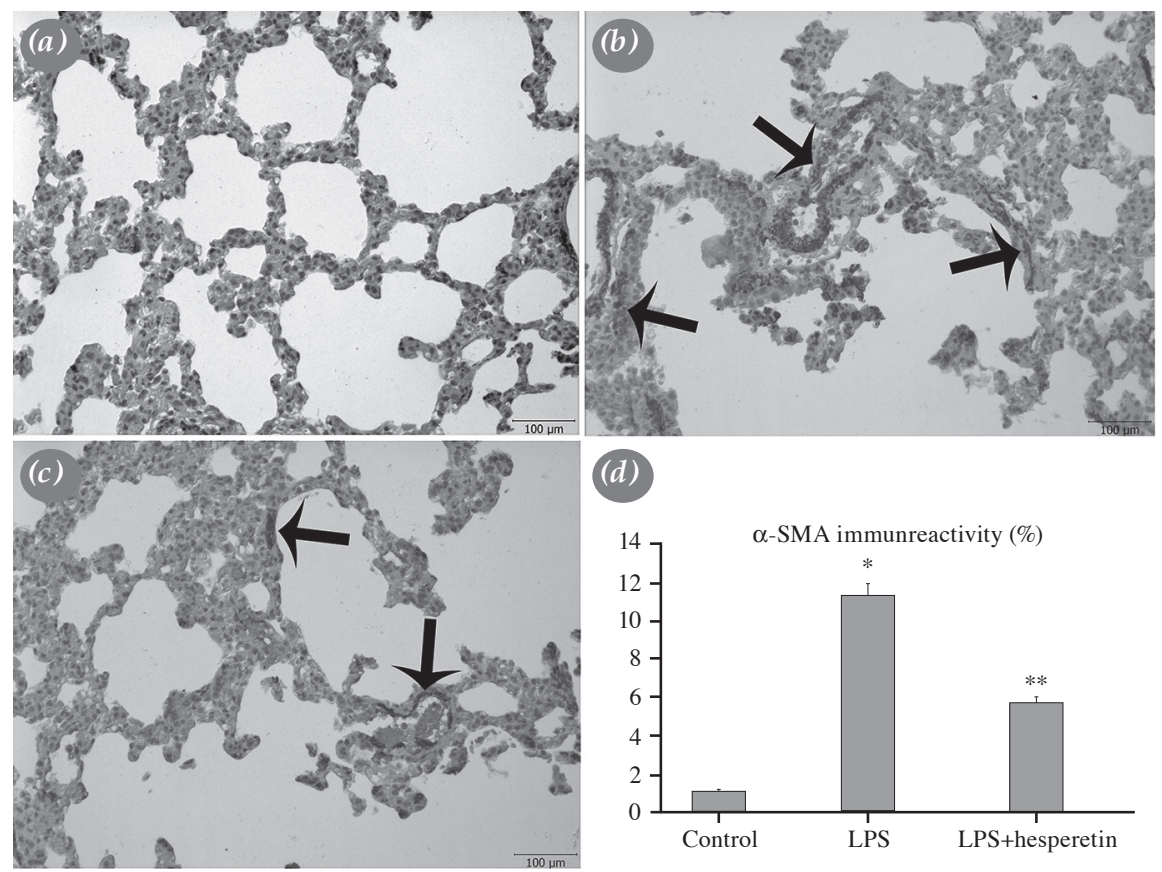

(d)

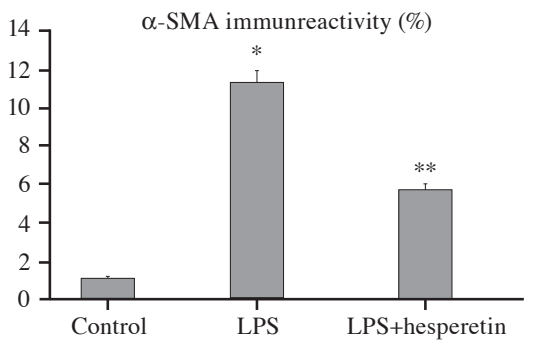

Figure 4. Immunohistochemical analysis of myofibroblast activation marker $\alpha$-SMA in lung tissue. (a) control, (b) LPS and (c) LPS+hesperetin, (d) comparison of the $\alpha$-SMA immunoreactivity of the groups.

Arrows: $\alpha$-SMA immunoreactivity; Scale bar: $100 \mu \mathrm{m}$, Mayer's hematoxylin counterstain; $\alpha$-SMA: Alpha-smooth muscle antigen; LPS: Lipopolysaccharide; * $\mathrm{p}<0.05$ compared to control group; ${ }^{* *} \mathrm{p}<0.05$ compared to LPS group.
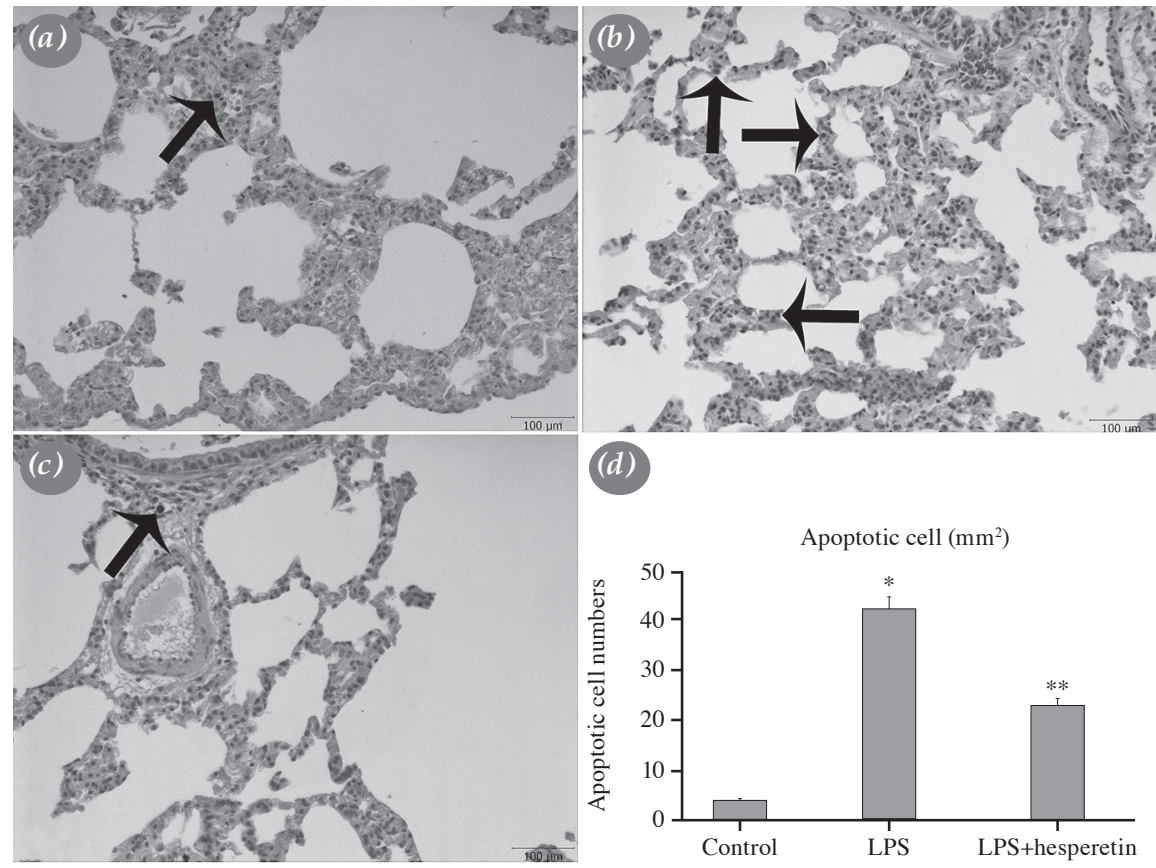

(d)

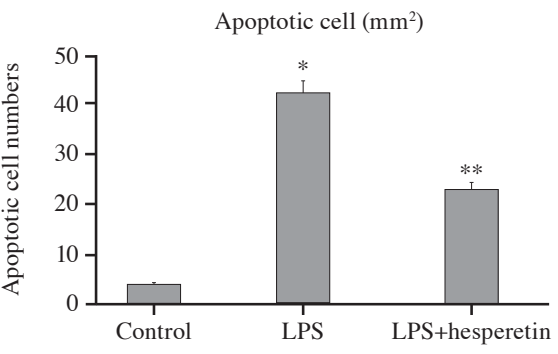

Figure 5. Effect of hesperetin on pulmonary apoptosis. (a) control, (b) LPS and (c) LPS+hesperetin, (d) comparison of the apoptotic cell numbers in the groups.

Arrows: TUNEL-positive cells; Scale bar: $100 \mu \mathrm{m}$, Mayer's hematoxylin counterstain; LPS: Lipopolysaccharide; $* \mathrm{p}<0.05$ compared to control group; ** $\mathrm{p}<0.05$ compared to LPS group. 
Table 1. Effect of hesperetin on TNF- $\alpha$, IL-1 $\beta$, IL-6, and IL-10 cytokine levels

\begin{tabular}{|c|c|c|c|c|}
\hline \multirow[b]{3}{*}{ Groups } & \multicolumn{2}{|c|}{ Lung tissue } & \multicolumn{2}{|c|}{ Serum } \\
\hline & TNF- $\alpha(\mathrm{pg} / \mathrm{mL})$ & IL-1 $\beta(\mathrm{pg} / \mathrm{mL})$ & IL-6 (pg/mL) & IL-10 (pg/mL) \\
\hline & Mean \pm SD & Mean \pm SD & Mean \pm SD & Mean \pm SD \\
\hline Control & $183.9 \pm 12.9$ & $18.5 \pm 2.7$ & $48.8 \pm 6$ & $544.7 \pm 37.2$ \\
\hline LPS & $527.9 \pm 76.8 \dagger$ & $64.3 \pm 7.9 \dagger$ & $329.8 \pm 16.8 \dagger$ & $400.8 \pm 50.4$ \\
\hline LPS+hesperetin & $318.5 \pm 39.6 \neq$ & $36.8 \pm 5.6 \neq$ & $189.8 \pm 9.2 \ddagger$ & $479 \pm 24.7$ \\
\hline
\end{tabular}

deviation; LPS: Lipopolysaccharide; $\uparrow \mathrm{p}=0.002$ compared to control group, $\$ \mathrm{p}=0.002$ compared to LPS group.

expression was detected in the LPS+hesperetin group compared to the LPS group ( $\mathrm{p}=0.002$, Figure $3 \mathrm{c}$ ). The iNOS-positive staining cell counts of the groups are presented in Figure 3d.

Alpha-smooth muscle antigen is used as a marker to determine the transformation of fibroblasts to myofibroblasts and the increase of collagen in the extracellular matrix. ${ }^{[23]}$ In the LPS group, increased fibroblast activation was detected in the alveolar wall compared to the control group (Figure $4 \mathrm{a}, \mathrm{b}$ ). The LPS+hesperetin group showed significantly decreased $\alpha$-SMA expression compared to LPS group (Figure 4c). The $\alpha$-SMA-positive staining cell counts of the groups are presented in Figure 4d.

The TUNEL examination findings are presented in Figure 5. Cells with dark-brown stained nuclei in the lung parenchyma were considered apoptotic cells. An increased apoptotic cell number was detected in the LPS group compared to the control group ( $\mathrm{p}=0.002$, Figure 5a, b). The apoptotic cell number showed a significant decline in the hesperetin-treated group compared to the LPS group (Figure 5c, d).

Inflammatory cytokine expression findings are shown in Table 1. Pulmonary The TNF- $\alpha$ and IL- $1 \beta$ dramatically increased in the LPS group compared to the control group. In addition, LPS stimulation increased proinflammatory IL-6 expression and decreased antiinflammatory IL-10 serum levels. Treatment with hesperetin resulted in a statistically significant reduction in proinflammatory TNF- $\alpha$, IL-1 $\beta$, and IL-6 levels in LPS+hesperetin group, compared to LPS group. Also, hesperetin treatment caused a non-significant increase in the serum anti-inflammatory IL-10 level compared to the LPS group $(p=0.15)$.

\section{DISCUSSION}

In recent years, there is a growing number of studies showing that phytochemicals with low toxic effects and less side effects can be used in different disease models for therapeutic purposes ${ }^{[17]}$ Flavonoids which are naturally present in plants and responsible for pigmentation are classified according to their molecular structure; flavones, flavonols and flavanones. Hesperetin, a flavonon which is abundant in citrus fruits such as lemon, grapefruit and orange, has strong antimicrobial, anti-inflammatory, and antioxidative effects in the in vivo and in vitro settings. ${ }^{[15]}$ In our study, we evaluated the protective effects of hesperetin in an LPS-induced ALI model in rats. Our study results, for the first time, demonstrated that hesperetin attenuated the LPS-induced inflammatory response in vivo by significantly inhibiting the expression of TNF- $\alpha$, IL-6, and IL-1 $\beta$.

Lipopolysaccharide is a component of the bacterial outer membrane and a potent stimulator of acute sepsis and chronic inflammation, also known as an endotoxin. ${ }^{[24]}$ Lipopolysaccharide-induced ALI is characterized by severe pulmonary edema and inflammatory cell infiltration in lung tissue. ${ }^{[25]}$ In our study, we found that LPS administration caused a significant increase in the W/D ratio, indicating the occurrence of pulmonary edema and inflammatory cell infiltration consistent with previous studies. ${ }^{[26,27]}$ Hesperetin treatment provided a significant decrease in the W/D ratio in the LPS+hesperetin group, compared to LPS group. To evaluate the effect of hesperetin on LPS-induced ALI, histopathological changes were scored on H-E-stained lung slides. Treatment with hesperetin resulted in a statistically significant decrease in histopathological change scores in the LPS-induced ALI model. Ultrastructural SEM analysis, Masson's trichrome staining, and W/D ratio findings also support this result.

Lipopolysaccharide is considered one of the most important triggers of pulmonary inflammation and expression of proinflammatory cytokines, which plays an important role in the pathogenesis of ALI 
and acute respiratory distress syndrome (ARDS). ${ }^{[28]}$ Experimental studies have shown that TNF- $\alpha$ and IL-6 play an important role in the pathogenesis of ALI. ${ }^{[29,30]}$ The Nf- $\kappa \beta$ is an important transcription factor which plays a central role in the regulation of immune responses, including the expression of genes of many inflammatory cytokines. ${ }^{[31]}$ Previous studies have demonstrated that $\mathrm{Nf}-\kappa \beta$ regulates the inflammatory and immune response to extracellular stimuli and plays a pivotal role in ALI development. ${ }^{[32,33]}$ In the LPSstimulated ALI model, it is well-known that toll-like receptor-4 (TLR4)-mediated Nf- $\kappa \beta$ activation increases the expression of TNF- $\alpha$ and IL- 6 proinflammatory cytokines, and both these cytokines activate $\mathrm{Nf}-\kappa \beta .{ }^{[31,34]}$ In our study, administration of hesperetin was shown to reduce $\mathrm{Nf}-\kappa \beta$ immunoreactivity in the LPS+hesperetin group, leading to a significant reduction in TNF- $\alpha$, IL-6, and IL-1 $\beta$ expression, compared to the LPS group. Also, hesperetin caused a non-significant increase in the anti-inflammatory IL-10 level compared to the LPS group $(p=0.15)$. In the present study, TNF- $\alpha$, locally produced in pulmonary tissue by LPS-induced macrophages, increased the severity of lung tissue damage by triggering neutrophil infiltration in lung tissue and activating the proinflammatory cascade.

Inducible nitric oxide synthase is a type of nitric oxide (NO) synthase which causes NO production and is closely related to the immune system. ${ }^{[35]}$ The iNOS is not expressed in healthy lung tissue and excessive iNOS expression may mediate lung injury. ${ }^{[36]}$ The Nf- $\kappa \beta$ is one of the main signal pathways which regulates iNOS expression. ${ }^{[37]}$ During pulmonary inflammation, activated macrophages produce large amounts of reactive oxygen species. As a result of the reaction of superoxide anions and NO, peroxynitrite, which is a highly oxidative species, can induce apoptosis. ${ }^{[38,39]}$ In our study, in addition to iNOS overexpression, increased pulmonary apoptosis was observed in the LPS group consistent with the previous studies. ${ }^{[35,40]}$ The hesperetin treatment group showed decreased iNOS expression, $\mathrm{Nf}-\kappa \beta$ activation, and pulmonary apoptosis. These findings suggest that pulmonary epithelial cell apoptosis, which plays an important role in the pathogenesis of ALI/ARDS and causes increased pulmonary capillary permeability, is suppressed by reducing neutrophil accumulation, proinflammatory cytokine production, and reduction of proinflammatory mediators.

Furthermore, $\alpha$-SMA is used as a marker of fibroblast activation in lung disease studies. ${ }^{[23]}$ The presence of $\alpha$-SMA indicates the occurrence of fibroblast transition toward myofibroblasts in lung tissue. Myofibroblasts can synthesize and secrete collagen to the extracellular matrix, thereby, leading to pulmonary interstitial fibrosis in the LPS-induced ALI model. ${ }^{[23,41]}$ Our results showed that LPS enhanced $\alpha$-SMA synthesis in lung tissue. In the LPS+hesperetin group, decreased $\alpha$-SMA immunoreactivity was determined compared to the LPS group.

Nonetheless, there are some limitations to the present study. The effect of hesperetin was evaluated for a short time $(24 \mathrm{~h})$. The protocol in this study involved the treatment of the rats with hesperetin $15 \mathrm{~min}$ after (without clinical symptoms) and the administration of LPS was not consistent with the patient treatment in the clinical setting. Also, this study was unable to explain whether the continuous/ or long-term administration of hesperetin enhanced its protective effect. Further long-term in vivo and in vitro studies designed in accordance with clinical settings are necessary to confirm the therapeutic effect of hesperetin in LPS-induced ALI.

In conclusion, hesperetin significantly decreased inflammatory cell infiltration, lung edema, and proinflammatory tumor necrosis factor-alpha, interleukin- 6 and interleukin- 1 beta in the rat model of lipopolysaccharide-induced acute lung injury. The mechanism of hesperetin involves reduced expression of tumor necrosis factor-alpha and interleukin-1 beta in lung tissue and suppressed activation of nuclear factorkappa beta in lung tissue also inhibited pulmonary apoptosis. Hesperetin also inhibited the transformation of fibroblasts into myofibroblasts in lung tissue. These results clearly demonstrate that hesperetin has a protective role in lipopolysaccharide-induced acute lung injury via reducing tumor necrosis factor-alpha, interleukin-1 beta, and alpha-smooth muscle antigen expression and nuclear factor-kappa beta activation. Our data suggest that hesperetin may be a useful agent for the treatment or improve the prognosis of lipopolysaccharide- induced acute lung injury.

\section{Declaration of conflicting interests}

The authors declared no conflicts of interest with respect to the authorship and/or publication of this article.

\section{Funding}

The authors received no financial support for the research and/or authorship of this article.

\section{REFERENCES}

1. Gao P, Zhao Z, Zhang C, Wang C, Long K, Guo L, et al. The therapeutic effects of traditional Chinese medicine Fusu agent in LPS-induced acute lung injury model rats. Drug Des Devel Ther 2018;12:3867-78. 
2. Meng L, Li L, Lu S, Li K, Su Z, Wang Y, et al. The protective effect of dexmedetomidine on LPS-induced acute lung injury through the HMGB1-mediated TLR4/NF- $\mathrm{KB}$ and PI3K/Akt/ mTOR pathways. Mol Immunol 2018;94:7-17.

3. Xu M, Cao FL, Zhang YF, Shan L, Jiang XL, An XJ, et al. Tanshinone IIA therapeutically reduces LPS-induced acute lung injury by inhibiting inflammation and apoptosis in mice. Acta Pharmacol Sin 2015;36:179-87.

4. Della Rocca G, Coccia C. Acute lung injury in thoracic surgery. Curr Opin Anaesthesiol 2013;26:40-6.

5. Baradaran Rahimi V, Rakhshandeh H, Raucci F, Buono B, Shirazinia R, Samzadeh Kermani A, et al. Anti-Inflammatory and Anti-Oxidant Activity of Portulaca oleracea Extract on LPS-Induced Rat Lung Injury. Molecules 2019;24. pii: E139.

6. Stearns-Kurosawa DJ, Osuchowski MF, Valentine C, Kurosawa S, Remick DG. The pathogenesis of sepsis. Annu Rev Pathol 2011;6:19-48.

7. Bayraktar O, Tekin N, Aydın O, Akyuz F, Musmul A, Burukoglu D. Effects of S-allyl cysteine on lung and liver tissue in a rat model of lipopolysaccharideinduced sepsis. Naunyn Schmiedebergs Arch Pharmacol 2015;388:327-35.

8. Liu JX, Li X, Yan FG, Pan QJ, Yang C, Wu MY, et al. Protective effect of forsythoside B against lipopolysaccharide-induced acute lung injury by attenuating the TLR4/NF- $\kappa \mathrm{B}$ pathway. Int Immunopharmacol 2019;66:336-46.

9. Wang J, Liu YT, Xiao L, Zhu L, Wang Q, Yan T. Antiinflammatory effects of apigenin in lipopolysaccharideinduced inflammatory in acute lung injury by suppressing COX-2 and NF-kB pathway. Inflammation 2014;37:2085-90.

10. Chen Z, Zhang X, Chu X, Zhang X, Song K, Jiang Y, et al. Preventive effects of valnemulin on lipopolysaccharideinduced acute lung injury in mice. Inflammation 2010;33:306-14.

11. Schuliga M. NF-kappaB Signaling in Chronic Inflammatory Airway Disease. Biomolecules 2015;5:1266-83.

12. Di R, Huang MT, Ho CT. Anti-inflammatory activities of mogrosides from Momordica grosvenori in murine macrophages and a murine ear edema model. J Agric Food Chem 2011;59:7474-81.

13. Ma H, Feng X, Ding S. Hesperetin attenuates ventilatorinduced acute lung injury through inhibition of NF- $\mathrm{KB}$ mediated inflammation. Eur J Pharmacol 2015;769:333-41.

14. Aranganathan S, Nalini N. Antiproliferative efficacy of hesperetin (citrus flavanoid) in 1,2-dimethylhydrazineinduced colon cancer. Phytother Res 2013;27:999-1005.

15. Ahmadi A, Hassandarvish P, Lani R, Yadollahi P, Jokar A, Abu Bakar S, et al. Inhibition of chikungunya virus replication by hesperetin and naringenin. RSC Adv 2016;6:69421-30.

16. Kumar B, Gupta SK, Srinivasan BP, Nag TC, Srivastava S, Saxena R, et al. Hesperetin rescues retinal oxidative stress, neuroinflammation and apoptosis in diabetic rats. Microvasc Res 2013;87:65-74.

17. Polat FR, Karaboga I, Polat MS, Erboga Z, Yilmaz A, Güzel S. Effect of hesperetin on inflammatory and oxidative status in trinitrobenzene sulfonic acid-induced experimental colitis model. Cell Mol Biol (Noisy-le-grand) 2018;64:58-65.
18. Bodduluru LN, Kasala ER, Barua CC, Karnam KC, Dahiya V, Ellutla M. Antiproliferative and antioxidant potential of hesperetin against benzo(a)pyrene-induced lung carcinogenesis in Swiss albino mice. Chem Biol Interact 2015;242:345-52.

19. Kao MC, Yang CH, Sheu JR, Huang CJ. Cepharanthine mitigates pro-inflammatory cytokine response in lung injury induced by hemorrhagic shock/resuscitation in rats. Cytokine 2015;76:442-8.

20. Karaboga I, Demirtas S, Karaca T. Investigation of the relationship between the Th17/IL-23 pathway and innateadaptive immune system in TNBS-induced colitis in rats. Iran J Basic Med Sci 2017;20:870-9.

21. Chen F, Liu Z, Wu W, Rozo C, Bowdridge S, Millman A, et al. An essential role for TH2-type responses in limiting acute tissue damage during experimental helminth infection. Nat Med 2012;18:260-6.

22. Hsu SM, Raine L, Fanger H. Use of avidin-biotin-peroxidase complex $(\mathrm{ABC})$ in immunoperoxidase techniques: a comparison between $\mathrm{ABC}$ and unlabeled antibody (PAP) procedures. J Histochem Cytochem 1981;29:577-80.

23. He Z, Zhu Y, Jiang $\mathrm{H}$. Inhibiting toll-like receptor 4 signaling ameliorates pulmonary fibrosis during acute lung injury induced by lipopolysaccharide: an experimental study. Respir Res 2009;10:126.

24. Bashir A, Banday M, Haq E. (2011). Lipopolysaccharide, Mediator of Sepsis Enigma: Recognition and Signaling. International Journal of Biochemistry Research \& Review 2011;1:1-13.

25. Matthay MA, Ware LB, Zimmerman GA. The acute respiratory distress syndrome. J Clin Invest 2012;122:2731-40.

26. Li G, Zhou CL, Zhou QS, Zou HD. Galantamine protects against lipopolysaccharide-induced acute lung injury in rats. Braz J Med Biol Res 2016;49:e5008.

27. Yao HW, Mao LG, Zhu JP. Protective effects of pravastatin in murine lipopolysaccharide-induced acute lung injury. Clin Exp Pharmacol Physiol 2006;33:793-7.

28. Zhang B, Liu ZY, Li YY, Luo Y, Liu ML, Dong HY, et al. Antiinflammatory effects of matrine in LPS-induced acute lung injury in mice. Eur J Pharm Sci 2011;44:573-9.

29. Xiao X, Yang M, Sun D, Sun S. Curcumin protects against sepsis-induced acute lung injury in rats. J Surg Res 2012;176:e31-9.

30. Huang R, Li M. Protective effect of Astragaloside IV against sepsis-induced acute lung injury in rats. Saudi Pharm J 2016;24:341-7.

31. Feng G, Jiang ZY, Sun B, Fu J, Li TZ. Fisetin Alleviates Lipopolysaccharide-Induced Acute Lung Injury via TLR4Mediated NF- $\kappa$ B Signaling Pathway in Rats. Inflammation 2016;39:148-57.

32. Zhang L, Yue Z. Nuclear factor- $\kappa \beta$ pathway and acute lung injury in hemorrhagic shock. Zhonghua Wei Zhong Bing Ji Jiu Yi Xue 2014;26:599-602.

33. Zhang Y, Du Z, Zhou Q, Wang Y, Li J. Remifentanil attenuates lipopolysaccharide-induced acute lung injury by downregulating the NF- $\kappa \beta$ signaling pathway. Inflammation 2014;37:1654-60. 
34. Wu Y, Liu Y, Huang H, Zhu Y, Zhang Y, Lu F, et al. Dexmedetomidine inhibits inflammatory reaction in lung tissues of septic rats by suppressing TLR4/NF- $\kappa \beta$ pathway. Mediators Inflamm 2013;2013:562154.

35. Kosutova P, Mikolka P, Kolomaznik M, Balentova S, Calkovska A, Mokra D. Effects of S-Nitroso-N-AcetylPenicillamine (SNAP) on Inflammation, Lung Tissue Apoptosis and iNOS Activity in a Rabbit Model of Acute Lung Injury. Adv Exp Med Biol 2016;935:13-23.

36. Lang JD, McArdle PJ, O'Reilly PJ, Matalon S. Oxidantantioxidant balance in acute lung injury. Chest 2002;122:314S-20S.

37. Tan ZH, Yu LH, Wei HL, Liu GT. Scutellarin protects against lipopolysaccharide-induced acute lung injury via inhibition of NF-kappaB activation in mice. J Asian Nat Prod Res 2010;12:175-84.
38. Zeng M, He W, Li L, Li B, Luo L, Huang X, et al. Ghrelin attenuates sepsis-associated acute lung injury oxidative stress in rats. Inflammation 2015;38:683-90.

39. Zhang HX, Liu SJ, Tang XL, Duan GL, Ni X, Zhu XY, et al. H2S Attenuates LPS-Induced Acute Lung Injury by Reducing Oxidative/Nitrative Stress and Inflammation. Cell Physiol Biochem 2016;40:1603-12.

40. Rudkowski JC, Barreiro E, Harfouche R, Goldberg P, Kishta $\mathrm{O}$, D'Orleans-Juste $\mathrm{P}$, et al. Roles of iNOS and nNOS in sepsis-induced pulmonary apoptosis. Am J Physiol Lung Cell Mol Physiol 2004;286:L793-800.

41. He Z, Zhu Y, Jiang $H$. Toll-like receptor 4 mediates lipopolysaccharide-induced collagen secretion by phosphoinositide3-kinase-Akt pathway in fibroblasts during acute lung injury. J Recept Signal Transduct Res 2009;29:119-25. 